\title{
Physiological Function of a DNA-Binding Protein from Starved Cells in Combating Diverse External Stresses in Escherichia coli
}

\author{
Joo Hyeong Lee', Su Jin Cheong ${ }^{1}$, Hun Taek $\mathrm{Oh}^{2}$, Woe Yeon $\mathrm{Kim}^{2}$ and Young Jun Jung² \\ ${ }^{1}$ Senior High School of Gyeongsang National University, ${ }^{2}$ Division of Applied Life Science, Gyeongsang National University, Jinju 660-701, \\ Korea
}

Received February 1, 2013 /Revised March 142013 / Accepted March 252013

\begin{abstract}
The DNA-binding protein from starved cells (DPS), originally identified as a DNA binding protein in Escherichia coli, is known to play an important role in DNA protection. The aim of this study was to evaluate the functional roles of DPS in E. coli against various kinds of external stresses by comparing the properties of wild-type $E$. coli cells and $d p s$ knockout mutant $E$. coli $(\triangle d p s)$ cells. Under various stress conditions, we measured the cell growth of the wild-type $E$. coli and the $d p s$ knockout mutant E. coli $(\triangle d p s)$ cells using a UV spectrophotometer. The growth rate of the cells was compared to investigate the functional roles of the DPS protein in $E$. coli. In comparison to the properties of the wild-type $E$. coli cells, the $d p s$ knockout mutant $E$. coli $(\triangle d p s)$ cells showed highly sensitive phenotypes under various stress conditions, such as heat shock, acidic $\mathrm{pH}$, nutrient deficiency, and different concentrations of reactive oxygen species (ROS), suggesting that DPS plays key roles in $E$. coli in combating diverse external stresses. The DPS DNA-binding protein in E. coli plays crucial roles in bacterial cell growth and in the protection of the cells from environmental stresses by tightly binding and preserving their DNA molecules.
\end{abstract}

Key words : E. coli, external stresses, DNA-binding Protein from Starved cells (DPS), cell growth

\section{서 론}

모든 생물 종들은 살아가면서 다양한 종류의 스트레스를 받고 그에 대한 저항성 능력을 통하여 환경스트레스로부터 자신을 보호하고 생존하며 종을 유지 보존하고 있다. 환경적 인 스트레스는 생물에게 직접적으로 해를 가하는 것이 대부분 이지만, 종종 DNA에 mutation 혹은 deletion을 일으켜서 $\mathrm{DNA}$ 을 손상시키고 잘못된 유전정보를 가지게 한다[26]. 그래 서 모든 생물들은 스스로 DNA를 보호하기 위하여 자체적인 보호하는 시스템을 가지고 있다. 대표적인 예로 진핵 생물은 histone 단백질을 가지고 있는데 이 histone 단백질은 작고, 염기성 성질을 가진다[20]. 이 단백질은 산성 성질을 가지는 $\mathrm{DNA}$ 와 강하게 결합함으로써 DNA를 nucleosome 형태로 압 축하고 nucleus 안에서 외부 스트레스에 대한 보호기능을 수 행한다. bacteria는 진핵 세포와 달리 핵이 없으며 DNA가 세 포질에 분포하고 있으나 histone 비슷한 특성을 가진 histone

\footnotetext{
*Corresponding author

Tel : +82-55-772-2584, Fax : +82-55-759-9363

E-mail : jun5763@hanmail.net

This is an Open-Access article distributed under the terms of the Creative Commons Attribution Non-Commercial License (http://creativecommons.org/licenses/by-nc/3.0) which permits unrestricted non-commercial use, distribution, and reproduction in any medium, provided the original work is properly cited.
}

유사 단백질을 여러 종류 가지고 있다. bacteria histone 유사 단백질은 DNA를 압축하여 nucleosome 형태로 만들지는 못 하지만, bacteria DNA와 결합하여 DNA를 안정화시킨다[9]. 원핵 생물에서 DNA-binding protein에 대한 연구를 수행한 결과, 배지의 영양분 결핍상태인 굶주린(starved) 대장균 내에 서 DNA 조절과 보호 기능을 가지는 새로운 DNA-binding protein를 발견하였는데 이것을 DPS (DNA-binding protein from starved cells)라고 명명하였다[1].

대장균에 존재하는 DPS는 167 개의 아미노산으로 구성되어 있으며 $19 \mathrm{kDal}$ 의 분자량을 가진다고 보고되었다. DPS는 $\mathrm{DNA}$ 결합단백질로서 $\mathrm{DNA}$ 의 특정한 서열을 구별하지 않고 유전물질과 결합함으로서 매우 안정한 형태의 DNA-단백질 복합체를 형성한다. 대장균 내 유전물질인 DNA가 DPS와 복 합체를 형성하면 유전자 절단효소(DNase)에 대한 저항성을 가지게 된다[1]. DPS의 구조는 지름 $45 \mathrm{~A}$ 인 Hole을 중심으 로 12 개의 동일한 subunit가 4 면 대칭으로 조립된 shell-like structure를 가지고 있다는 사실이 보고되었다[10]. DPS 단위 체(subunit)는 기본적으로 4 개의 나선형 입체 구조를 가지고 있고, 이 나선형 구조는 $\mathrm{aI}, \mathrm{a} \Pi, \mathrm{aIV}, \mathrm{aV}$ 로 구성된다. $\mathrm{aI}$ 과 $a \Pi$ 는 $a \mathrm{IV}$ 와 $\mathrm{aV}$ 와 연결되는데 중간의 긴 loop 안의 짧은 나선 형 aIII 구조를 나타낸다. 이러한 구조적 특이성에 의하여 DPS 는 각 단위체간 상호작용을 통하여 입체구조를 형성하며 $\mathrm{DNA}$ 와 결합할 수 있는 구조적 특성을 가지게 된다. 결국 DPS 
는 DNA와 결합하게 되고, 이들 DNA-단백질 결합체들은 중 합과정을 거쳐 압축된 거대한 복합체 구조를 형성하여 환경변 화에 대하여 안정하게 유전물질을 보호하게 된다. 또한 DPS는 $a$ I 과 $a \Pi$ 에 존재하는 site 1과 2에 존재하는 아미노산 잔기들 (site 1: His31, Asp58, Glu62, site 2: His43, Glu62, Glu47)에 의해서 $\mathrm{Fe}^{2+}$ 와 결합한다[23]. DPS 단백질의 구조와 이 단백질 이 DNA와 결합하여 DNA를 안정화시키는 모델은 여러 논문 들에 의해 보고되어 잘 밝혀져 있다[6, 11]. 이러한 구조적 특이 성에 의하여 DNA를 유전자 분해효소인 DNase로부터 방어하 는 기능을 수행한다. DPS는 ferritin과 유사한 단백질로써 Fenton 반응에 의한 피해를 예방하는 임무를 수행하는데 크나 큰 기여를 한다[29]. 처음 DPS를 발견하였을 때, 자기 스스로 단백질을 조절될 수 있을 것이라는 단서가 보고되었지만 DPS 의 과 발현 혹은 손실이 어떤 특정한 유전자와도 상위 혹은 하위 조절에 있어 직접 연관되는 것은 보고되지 않고 있다. 그래서 DPS 단백질의 기능을 조절하는 조절기능의 생체물질 은 밝혀지지 않았으며 이에 대한 연구가 필요한 상황이다[4]. 12개 서브 유닛으로 구성된 Listeria innocua 종의 ferritin과 비 슷한 구조의 대장균 DPS는 DNA에 결합하여 활성 산소 종에 의한 공격을 보호하는 기전이 $\mathrm{Fe}^{2+}$ 과 결합하는 저장 단백질인 ferritin과 유사한 기능을 수행하고 있음이 보고되었다[29]. DPS의 dinuclear ferrocidase sites로 추정되는 12 개 부분은 각 각 단백질의 인접한 서브 유닛의 6 개의 접점에 위치한다. 두 개의 철 이온은 환원된 $\mathrm{H}_{2} \mathrm{O}_{2}$ 의 한 분자를 산화하고 이로 인하 여 Fenton 반응 (Fenton chemistry: $\mathrm{Fe}^{2+}+\mathrm{H}_{2} \mathrm{O}_{2} \rightarrow \mathrm{Fe}^{3+}+\mathrm{OH}^{-}$ $\left.+{ }^{\bullet} \mathrm{OH}\right)$ 를 경유한 hydroxyl radical 형성을 방지한다 $[8,12,13$, $18,19,22$, 27].

이러한 DPS의 구조적 특성이나 DNA와의 결합형태, 그리고 $\mathrm{DPS}$ 와 DNA 와의 결합에 작용하는 화학구조나 잔기 등의 형 태적 특성과는 달리, DPS 단백질의 생체 내 역할과 특히 외부 의 환경적 스트레스가 왔을 때 이 단백질이 어떠한 기능을 수행하는지에 대한 연구는 거의 이루어지지 않은 상태이다. 따라서, 본 연구에서는 다양한 외부의 환경적 스트레스에 대 하여 DPS 단백질의 생체 내 기능이 무엇인지, 그리고 대장균 의 생육에 DPS 단백질이 어떠한 역할을 수행하는 지에 대한 연구를 수행하였다. 이러한 연구를 위하여 DPS 단백질을 코딩 하는 $d p s$ 유전자를 대장균에서 제거한 돌연변이 대장균을 제 조하고 이 변이 대장균의 특성을 정상적인 대장균(wild type E. coll)과 비교하며 생육 및 성장속도 등을 관찰하여 보았다. 이러한 실험을 통하여 대장균에 존재하는 DPS는 산화적인 스 트레스, 높은 압력, 자외선과 감마선 노출, 과도한 금속성 물질 에 대한 노출 등과 같은 다양한 스트레스에 대하여 강력한 보호기능을 수행함을 관찰함으로서, 하등생명체의 유전물질 인 DNA 물질보호는 대장균의 생육과 보존에 결정적인 역할 을 수행함을 알 수 있었다.

\section{재료 및 방법}

\section{균주 및 실험재료}

본 실험에 사용한 dps knock-out 대장균 $(\triangle d p s$ E.coll)은 유 전자원센터(genetic stock center)에서 주문, 구입하였다. $\triangle$ $d p s$ E.coli에서 $d p s$ 유전자의 결손상태를 확인하기 위하여 $d p s$ 유전자(ACCESSION: NP_41533)를 코딩하는 일부 핵산조각 에 대한 염기는 Oligonucleotide Bioneer Co.에서 합성하여 사용하였다.

유전자 증폭을 위한 Colony PCR 실험을 위한 FIRE Tag DNA Polymerase 효소는 Solid BioDyne 회사로부터 구입하 여 사용하였다.

\section{세포 내 유전자 증폭(Colony Polymerase chain reaction, $\mathrm{PCR})$}

세포 내부의 $\mathrm{DNA}$ 를 직접 이용하여 유전자 증폭과정(PCR) 을 수행하기 위하여 야생형 대장균(WT E. colli)와 $d p s$ 유전자가 제거된 대장균( $\triangle d p s$ E. coll $)$ 세포 $5 \mu 1$ 를 2차수 $45 \mu l$ 에 희석 시킨 다음, 끓는 물에서 5 분간 꼻임으로써 세포를 파괴하고 세포내부의 DNA를 용출시키도록 한다. 유전자 증폭과정의 실험을 위하여 유전자 증폭용 프라이머(primer)는 보고된 $d p s$ 유전자 서열에 근거하여 특이적으로 설계하였다. dps 유전자 $(504 \mathrm{bp})$ 의 특이적 프라이머의 염기서열 정보는 다음과 같다. dps Forward primer (BamHI)는 5'-GGATCCATGAGCACC GCGAAACTG-3'이고, dps Reverse primer (HindIII)는 5'AAGCCTTTATTCAATGTTGCTTTCAATAAACCACAG - $3^{\prime}$ 이다. 유전자 증폭 조건은 아래와 같이 실험하였다; $95^{\circ} \mathrm{C}$ 에서 5 분간 반응, $95^{\circ} \mathrm{C}$ 에서 30 초 반응, $58^{\circ} \mathrm{C}$ 에서 30 초와 $72^{\circ} \mathrm{C}$ 에서 1 분을 35 회 반복 반응, $72{ }^{\circ} \mathrm{C}$ 에서 10 분 반응하였다. 반응하여 증폭된 유전자는 $0.8 \%$ 아가로스 겔을 사용하여 전기영동 법에 의하여 유전자의 존재유무와 크기, 이동속도 등을 관찰, 확인 하였다[24].

\section{최소배지에서의 대장균 생장측정}

M9 배지 $\left(\mathrm{CaCl}_{2} 0.015 \mathrm{~g} / \mathrm{l}, \mathrm{Na}_{2} \mathrm{HPO}_{4} 6 \mathrm{~g} / \mathrm{l}, \mathrm{KH}_{2} \mathrm{PO}_{4} 3 \mathrm{~g} / \mathrm{l}\right.$, $\mathrm{NaCl} 0.5$ g/l, NH $\mathrm{Cl}_{1} 1 \mathrm{~g} / \mathrm{l}, \mathrm{MgSO}_{4} 0.5 \mathrm{~g} / \mathrm{l}$, Glucose $2.0 \mathrm{~g} / 1$ 포함) $35 \mathrm{ml}$ 에 야생형 대장균과 $\triangle d p s$ E.coli 세포 $500 \mu 1$ 를 최소배지 환경하에서 배양하며 광학분광계(photo-spectrometer)를 이용하여 세포의 흡광도를 $600 \mathrm{~nm}$ 에서 한 시간마 다 측정하여 48 시간 동안 세포생장을 관찰하였다.

\section{산화적 스트레스에 의한 변화 측정}

LB 배지 $(\mathrm{NaCl} 0.35 \mathrm{~g} / \mathrm{l}$, Tryptone $0.35 \mathrm{~g} / \mathrm{l}$, Yeast extract $0.175 \mathrm{~g} /$ ) $35 \mathrm{ml}$ 에 야생형 대장균과 $\triangle d p s$ E.coli 세포를 각각 $500 \mu$ 씩 접종하고 산화적 스트레스를 유발하는 물질인 과산 화수소의 농도를 $0.5 \mathrm{mM}, 1 \mathrm{mM}$ 로 첨가하여 세포의 생장 환경 
에 따른 세포의 성장속도를 관찰하였다. 용액의 세포는 $37^{\circ} \mathrm{C}$ 에서 배양하며 광학분광계를 이용하여 흡광도 $600 \mathrm{~nm}$ 에서 한 시간마다 측정하여 48 시간 동안 세포생장을 관찰하며 세포성 장에 대한 산화적 스트레스의 영향을 관찰하였다

\section{열 충격(heat shock) 스트레스에 의한 세포성장 변화 측정}

$\mathrm{LB}$ 배지 $35 \mathrm{ml}$ 에 야생형 대장균과 $\triangle$ dps E.coli 세포를 각각 $500 \mu 1$ 씩 접종하고 $45^{\circ} \mathrm{C}$ 로 예열된 수조에서 배양하며 광학분 광계를 사용하여 $600 \mathrm{~nm}$ 에서의 세포 흡광도를 측정하였다. 본 실험을 통하여 열 충격에 대한 대장균의 생육에 있어서 DPS 단백질의 유무가 나타내는 영향을 관찰할 수 있었다.

\section{산화스트레스를 유발하는 중금속 $\left(\mathrm{Fe}^{2+}\right)$ 의 영향 측정}

$\mathrm{LB}$ 배지 $35 \mathrm{~m}$ 에 야생형 대장균과 $\triangle d p s$ E.coli 세포를 각각 $500 \mu \mathrm{ll}$ 씩 접종하고 Fenton 반응을 유도하는 물질인 $\mathrm{FeCl}_{2}$ 을 농도를 달리한 배양조건에서 대장균 세포의 생장속도를 측정 하였다. 세포는 $37^{\circ} \mathrm{C}$ 에서 배양하면서 세포성장을 광학분광계 를 이용하여 흡광도 $600 \mathrm{~nm}$ 에서 세포성장을 한 시간마다 측정 하여 7시간 동안 세포생장을 관찰하였다. 세포성장 속도의 변 화를 관찰함으로써 산화스트레스를 유발하는 중금속의 존재 가 세포성장에 주는 정도를 관찰하고 특히 DPS단백질의 영향 을 측정할 수 있었다.

\section{$\mathrm{pH}$ 에 의한 변화 측정}

배지의 $\mathrm{pH} 5.0$ 를 달리한 조건으로 만든 LB 배지 $35 \mathrm{ml}$ 에 야생형 대장균과 $\triangle$ dps E.coli 세포를 각각 $500 \mu \mathrm{\mu l}$ 씩 접종하였 다. 세포는 $37^{\circ} \mathrm{C}$ 에서 배양하면서 용액의 세포는 $37^{\circ} \mathrm{C}$ 에서 배 양하며 광학분광계를 이용하여 흡광도 $600 \mathrm{~nm}$ 에서 세포성장 을 한 시간마다 측정하여7시간 동안 세포생장을 관찰하였다. 세포성장 속도의 변화로 배지내의 수 $\mathrm{pH}$ 가 세포의 성장에 미
치는 영향을 관찰할 수 있으며, 특히 DPS단백질의 영향을 측 정할 수 있었다.

\section{결 과}

DPS 단백질을 코딩하는 $d p s$ 유전자 결손 대장균 $(\Delta d p s$ $E . c o l /)$ 균주에서의 dos유전자 knock-out 확인

대장균 세포 내에서 유전물질인 DNA와 결합하는 DPS 단 백질의 생체 내 기능을 규명하고자 하였다. 이 단백질을 코딩 하는 유전자를 여러 종의 bacteria에서 Clustal W 소프트웨어 를 이용하여 조사해 본 결과, Fig. 1 과 같이 DPS 단백질들 간에 매우 보존된 아미노산 서열을 가지고 있음으로써 진화적으로 잘 보존되며 유전되고 있음을 알 수 있다. 대장균 세포 내에서 $\mathrm{DPS}$ 의 기능을 규명하기 위한 실험을 수행하기 위하여 $d p s$ knockout 세포인 $\triangle d p s$ E.coli 균주를 분양 받았다. 분양 받은 돌연변이 대장균 세포를 실제로 $d p s$ 유전자가 결손 된 대장균 인지의 여부를 확인하기 위하여 세포 내 유전자 증폭(Colony Polymerase chain reaction, PCR) 실험을 수행하였다. 먼저 야 생형 대장균과 $\triangle d p s$ E.coli 균주 세포를 이용하여 재료 및 방법 에서 설명한 것과 같이 각각의 대장균 균주 세포를 끓는 물에 서 5 분간 끓임으로써 세포를 파괴하고 세포내부의 DNA를 용 출시키도록 하였다. 그리고 용출된 DNA를 주형 가닥으로 하 여 특이적으로 결합하는 프라이머를 이용하여 dos유전자를 유 전자 증폭 실험 방법으로 증폭시켰으며, 증폭된 유전자를 이 용하여 유전자의 크기, 이동속도 등을 $0.8 \%$ 아가로스 겔에서 전기영동방법으로 확인하였다. 그 결과, 야생형 대장균에서 용출된DNA를 주형 가닥으로 사용하여 증폭한 유전자에는 $504 \mathrm{bp}$ 의 $d p s$ 유전자가 존재한다는 것을 확인하였다. 하지만 $\triangle d p s$ E.coli 균주로부터 용출된 DNA를 주형 가닥으로 사용하

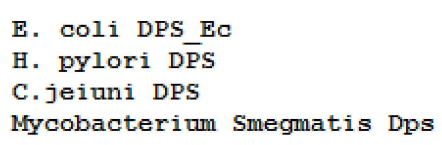

E. coli DPS Ec

H. pylori $\overline{D P S}$

C.jeiuni DPS

Mycobacterium Smegmatis Dps
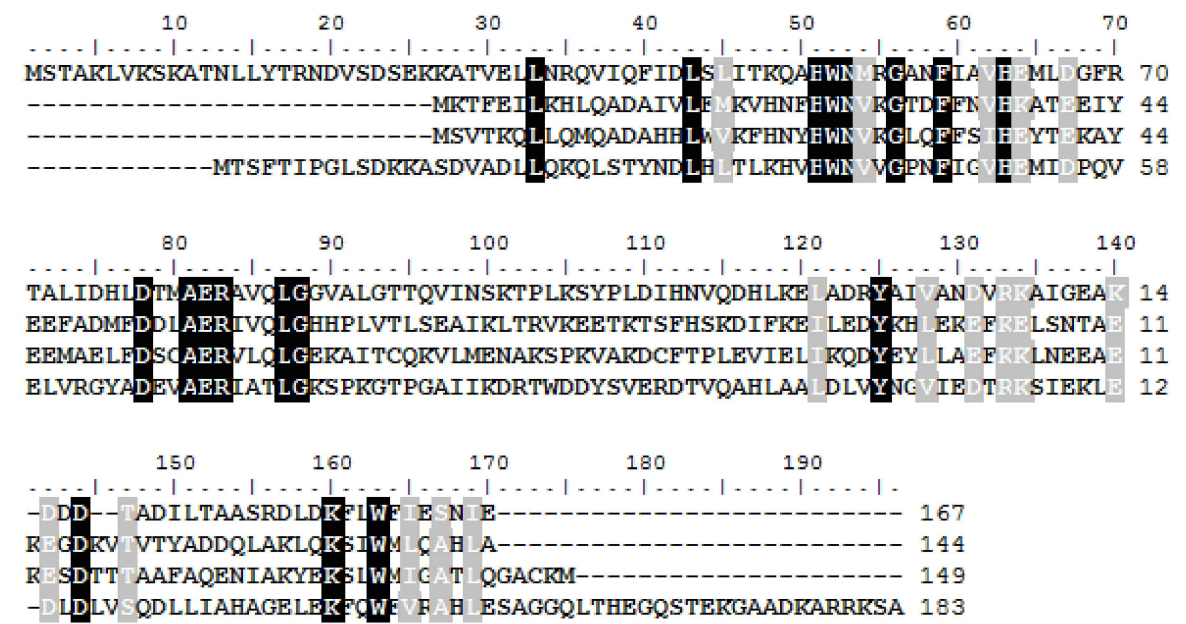

-D LDLV QDLLIAHAGELEK FQWF F H ESAGGQLTHEGQSTEKGAADKARRKSA 183

Fig. 1. Amino acid seqeunce comparison of E. coli DPS with those of other DPS proteins in prokaryotic cells. Sequence alignment was performed using software clustal W. 


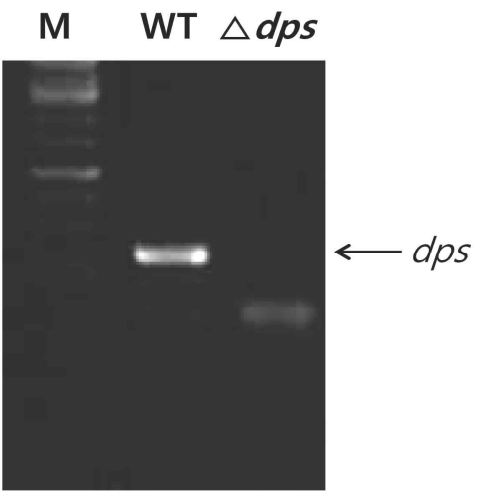

Fig. 2. Confirmation of $d p s$ gene in wild-type $E$. coli and $d p s-$ knock out in mutant $E$. coli $(\triangle d p s)$ cells by polymerase chain reaction (PCR) technique. In left lane, $\mathrm{M}$ indicates the DNA standard marker.

여 증폭한 유전자에서는 $d p s$ 유전자에 해당하는 크기의 유전 자가 증폭되지 않았다는 사실을 아가로스 전기영동 방법으로 확인하였다(Fig. 2). 결국, $\triangle d p s$ E.coli 균주에는 $d p s$ 유전자가 결손 되었다는 사실을 확인할 수 있었고, 이 균주의 특성을 야생형 대장균의 특성과 비교함으로써 대장균 내에 존재하는 DPS 단백질의 생체 내 기능을 규명하는 실험들을 수행하였다.

\section{영양 결핍 상태에서 DPS 단백질이 대장균의 생육에 미치 는 영향}

대장균 세포 내에서 DNA와 결합하여 DNA-DPS 결합형태 를 유지하는 DPS 단백질이 대장균의 생육에 미치는 영향을 관찰하여 보았다. 이 실험을 수행하기 위하여 야생형 대장균 과 $d p s$ 유전자의 결손이 확인된 $\triangle d p s$ 대장균 균주를 사용하였 다. 이들 균주가 대장균이 살아가는 데 요구되는 영양분의 결 핍상태에서 DPS 단백질 역할을 규명하기 위하여 최소한의 영 양분만을 함유한 $\mathrm{M} 9$ 최소배지[21]를 사용하여 대장균을 배양
하며 성장속도 변화를 관찰하였다. 이와 같은 영양 부족 환경 에서는 미생물의 생육활동에 필요한 대사활동 수행을 위한 영양분이 부족하기 때문에 야생형 대장균의 경우에도 정상적 인 세포 생장을 하기 힘들다는 것을 확인할 수 있었다. 따라서 영양분이 충분한 정상배지에서의 생육속도(Fig. $3 \mathrm{~A}$ )보다 영양 분 결핍의M9 배지에서는 대장균 성장속도 저하가 관찰되었으 며, 특히 $d p s$ 유전자 결손 대장균 세포의 생장 곡선은 야생형 대장균의 성장속도보다 뚜렷하게 낮은 성장속도를 보임을 확 인할 수 있었다(Fig. $3 \mathrm{~B})$. 이러한 결과는 미생물의 생육속도를 비교한 막대그래프(Fig. 3C)에서 보다 분명하게 확인할 수 있 었다. 본 실험의 결과, 대장균 세포의 DNA와 결합하여 DPS단 백질은 미생물의 생육에 필요한 영양 결핍상태에서 유전자 보호라는 기능을 통하여 영양분 부족에 의한 스트레스로부터 대장균을 보호하는 중요한 기능을 수행함을 알 수 있었다.

산화스트레스 존재 하에서 DPS 단백질이 대장균의 생육에 미치는 영향

생명체는 살아가는 과정 동안 다양한 외부 스트레스를 접하 게 되고 이러한 스트레스는 세포내부에서 활성산소종의 생성 으로 신호가 전달된다는 것이 잘 보고되어 있다. 특히 환경스 트레스에서 세포 보호에 연관되어 DPS 단백질이 중요한 기능 을 수행한다는 사실 $[2,14,22,28]$ 과 대장균 생장의 증식기 동 안에 세포를 보호하는 기능을 수행한다는 사실도 보고되었다 [19]. 따라서 이러한 외부의 환경적 스트레스에 대한 DPS 단백 질의 기능에 대한 보고들을 바탕으로, 본 실험에서는 생체 내 산화스트레스를 유발하는 활성산소종의 일종인 과산화수소 를 배지에 첨가한 다음, 야생형 대장균과 $\triangle d p s$ Ecoli 돌연변이 균주를 배양하며 세포 내 DPS단백질의 기능을 관찰하여 보았 다. 과산화수소를 처리한 후 대장균 세포의 생장속도와 생장 률을 측정하였다. Fig. $4 \mathrm{~A}$ 에서 보는 것과 같이 산화스트레스가 없는 상태에서는 야생형 대장균이나 $\mathrm{dps}$ 유전자가 결손된
A

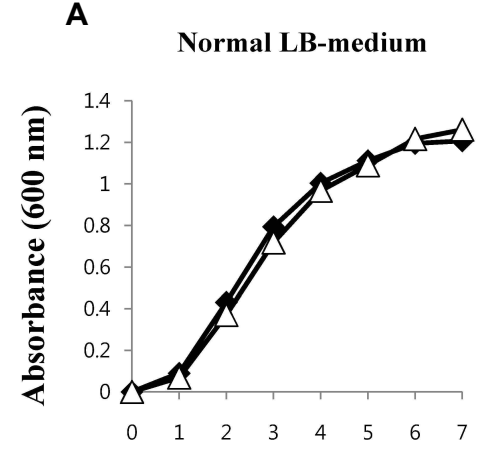

Time (hr)
B

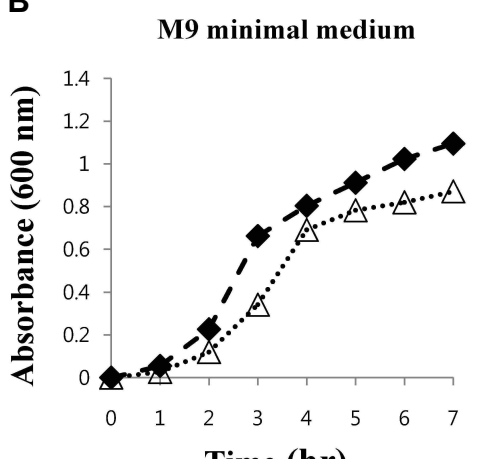

C

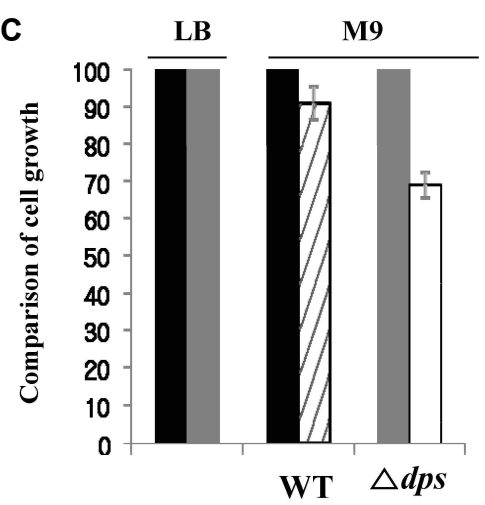

Fig. 3. Growth curve of wild-type $E$. coli $(\checkmark)$ and $d p s-$ knock out mutant $(\triangle d p s) E$. coli cells $(\triangle)$ cultured at $37^{\circ} \mathrm{C}$ in normal LB (Luria-Bertani) media (A) and M9 minimal (B) media. Cell growth was measured at indicated times (0, 1, 2, 3, 4, 5, 6, $7 \mathrm{hr}$ ) by UV-spectrorphotometer in absorbance $600 \mathrm{~nm}$. Cell densities of $\triangle d p s$ cells at $7 \mathrm{hr}$ were compared with those

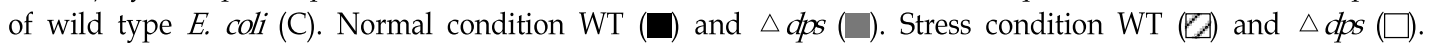


A

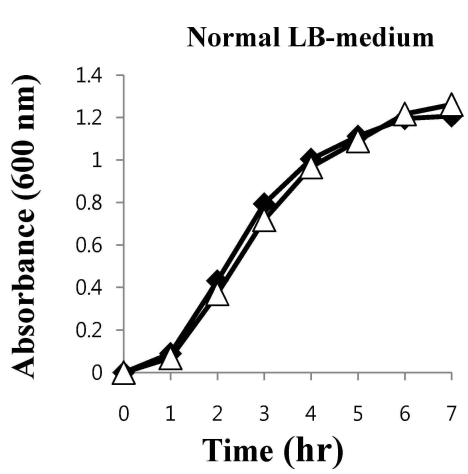

B

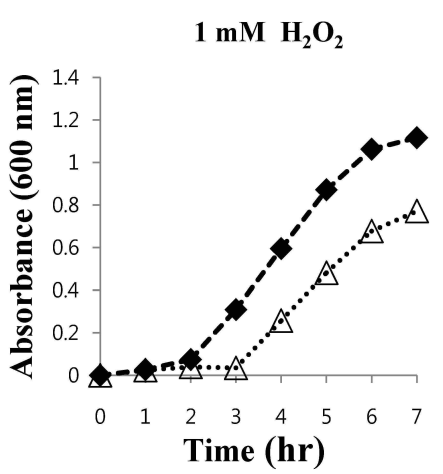

C

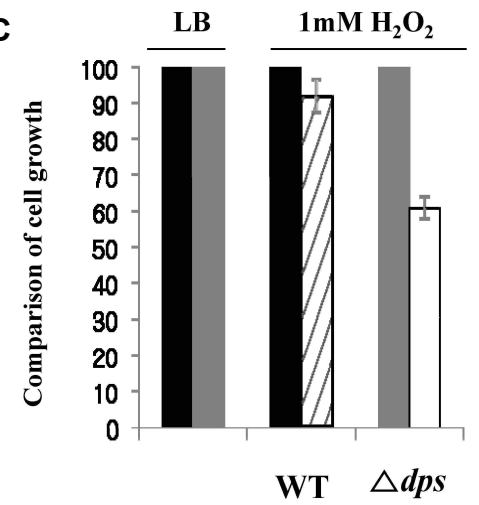

Fig. 4. Growth curve of wild-type $E$. coli $(\checkmark)$ and dps- knock out mutant $(\triangle d p s) E$. coli cells $(\Delta)$ cultured at $37^{\circ} \mathrm{C}$ in LB media in the absence (A) or presence of $1 \mathrm{mM} \mathrm{H}_{2} \mathrm{O}_{2}$ (B). Cell growth was measured at indicated times $(0,1,2,3,4,5,6,7 \mathrm{hr})$ by UV-spectrorphotometer in absorbance $600 \mathrm{~nm}$. The cell densities of $\Delta$ dps cells at $7 \mathrm{hr}$ were compared with those of wild type E. coli (C). Normal condition WT $(\square)$ and $\triangle d p s(\square)$. Stress condition WT $(\square)$ and $\triangle d p s(\square)$.

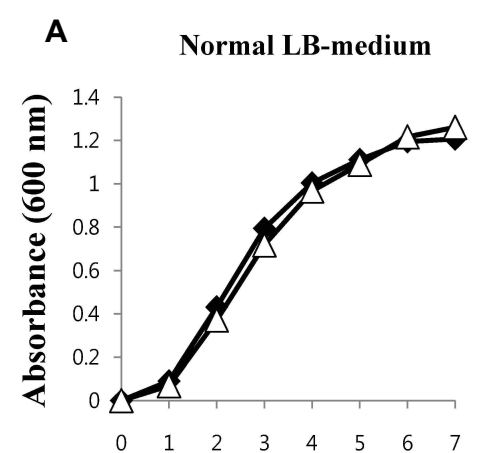

Time (hr)
B

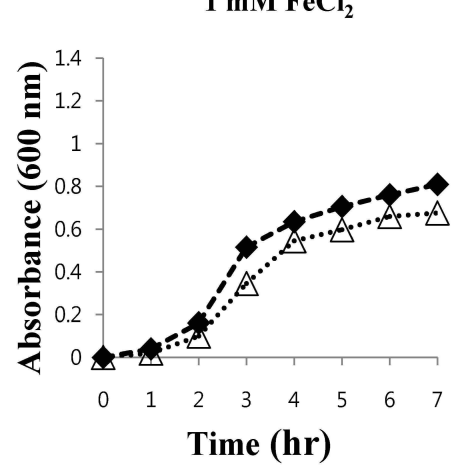

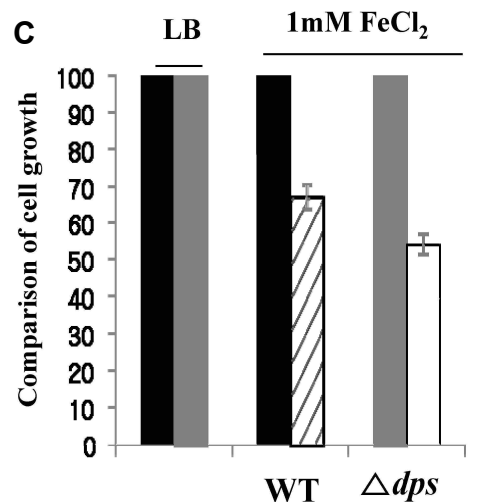

Fig. 5. Growth curve of wild-type $E$. coli $(\checkmark)$ and dps-knock out mutant $(\triangle$ dps $) E$. coli cells $(\triangle)$ cultured at $37^{\circ} \mathrm{C}$ in LB media in the absence (A) or presence of $1 \mathrm{mM} \mathrm{FeCl}$. Cell growth was measured at indicated times $(0,1,2,3,4,5,6,7 \mathrm{hr})$ by UV-spectrorphotometer in absorbance $600 \mathrm{~nm}$. The cell densities of $\Delta d p s$ cells at $7 \mathrm{hr}$ were compared with those of wild type E. coli (C). Normal condition WT $(\square)$ and $\triangle d p s(\square)$. Stress condition WT $(\square)$ and $\triangle d p s(\square)$.

$\triangle d p s$ E.coli 돌연변이 균주 모두 왕성한 생육을 보임을 확인하 였다. 하지만, 미생물 배지에 $1 \mathrm{mM}$ 의 과산화수소를 첨가한 배양조건에서는 야생형 대장균도 약간의 생육속도 저해가 나 타남을 관찰할 수 있었다. 특히 중요한 점은, dps유전자가 결손 된 $\triangle d p s$ E.coli 돌연변이 균주는 과산화수소의 존재 하에서 대장균의 생육속도가 심각하게 저해됨을 확인할 수 있었다 (Fig. 4B). 이러한 결과는 대장균 생육속도를 비교한 막대그래 프(Fig. 4C)에서 확연히 알 수 있었다. 이러한 산화스트레스 물질의 존재 하에 대장균의 생육속도에 미치는 영향을 관찰한 실험결과로부터, 대장균 세포 내 유전자와 강한 결합을 하는 DPS 단백질이 산화적 스트레스 동안에 대장균 세포를 보호하 는 매우 중요한 기능을 한다는 사실을 확인함으로서, DPS 단 백질이 대장균의 생육에 필수적 기능을 수행함을 알 수 있었 다.

산화스트레스는 중금속과 산소의 존재 하에서 강하게 유발 된다. 즉 과도한 양의 철은 산소의 존재 하에 Fenton 반응
(Fenton reaction: $\mathrm{Fe}^{2+}+\mathrm{H}_{2} \mathrm{O}_{2} \rightarrow \mathrm{Fe}^{3+}+\mathrm{OH}^{-}+{ }^{\bullet} \mathrm{OH}$ )을 거쳐 생물체의 생육에 매우 해로운 hydroxyl radical 생산을 유발하 게 된다. 따라서, 대장균의 생육과정에서 DPS 단백질의 존재 유무가 Fenton 반응에 의한 산화스트레스에 대한 저항성을 가질 수 있는지를 실험하여 보았다(Fig. 5). 야생형 대장균과 $\triangle$ dps E.coli 돌연변이 균주의 배양액에 $1 \mathrm{mM} \mathrm{FeCl}_{2}$ 를 처리하 며 세포의 성장속도를 측정하여 본 결과, $1 \mathrm{mM} \mathrm{FeCl}_{2}$ 를 처리 한 배지에서 $\triangle d p s$ Ecoli 돌연변이 균주는 야생형 대장균에 비하여 생육속도가 현저히 저하되는 것을 관찰함으로써 DPS 단백질이 Fenton 반응에 의한 산화적 스트레스로부터 대장균 을 잘 보호하고 있다는 사실을 확인할 수 있었다.

열 충격(Heat shock) 및 산화스트레스를 동시에 처리한 스트레스 하에서 DPS 단백질의 대장균 생육에 미치는 영향

생물체는 이들이 살아가는데 필요한 적절한 온도가 유지될 때 생육하며 번식하고 종을 보존하게 된다. 이러한 적정온도 

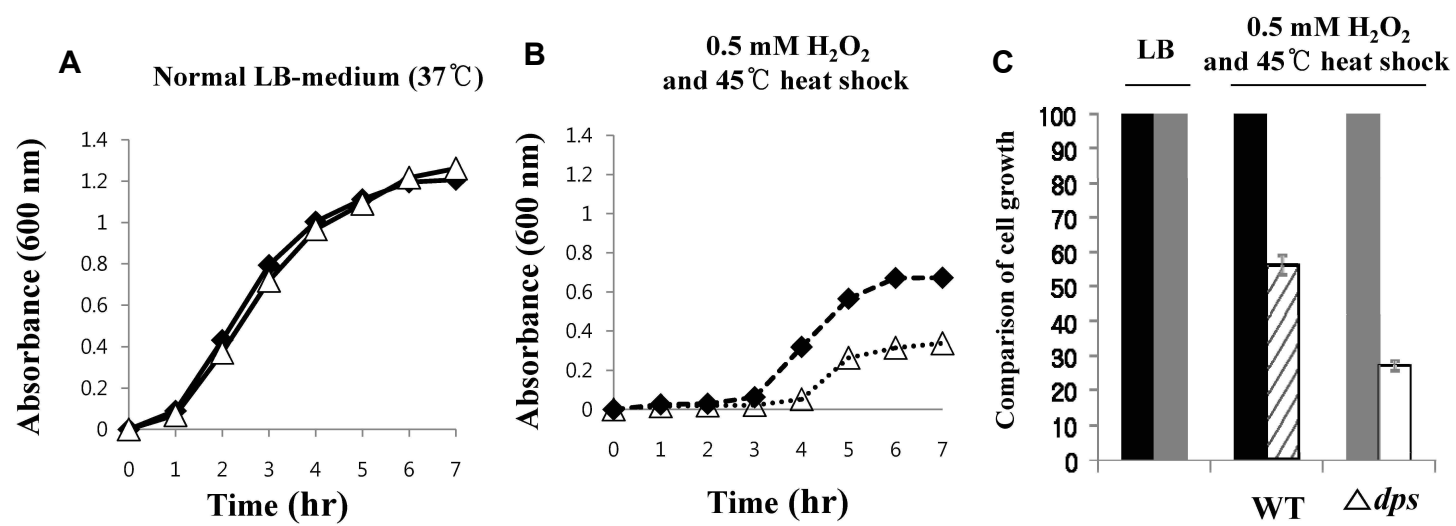

Fig. 6. Growth curve of wild-type $E$. coli $(\checkmark)$ and dps- knock out mutant $(\triangle d p s)$ E. coli cells $(\triangle)$ cultured in LB media at different temperature of $45^{\circ} \mathrm{C}$ in the absence (A) or presence of $0.5 \mathrm{mM} \mathrm{H}_{2} \mathrm{O}_{2}$ (B). Cell growth was measured at indicated times $(0,1,2,3,4,5,6,7 \mathrm{hr})$ by UV-spectrorphotometer in absorbance $600 \mathrm{~nm}$. The cell densities of $\triangle d p s$ cells at $7 \mathrm{hr}$ were compared with those of wild type E. coli $(\mathrm{C})$. Normal condition WT $(\square)$ and $\triangle d p s(\square)$. Stress condition WT (\) and $\triangle d p s(\square)$.

를 벗어날 경우, 생물체는 다양한 생체방어 시스템을 구동하 여 생존할 수 있도록 노력하지만 이러한 범위를 넘어서면 살 지 못하고 죽어가게 된다. 따라서 대장균 세포 내에서 환경적 스트레스를 극복하는 데 중요한 기능을 한다고 보고 된 DPS 단백질이 과산화수소 $(0.5 \mathrm{mM})$ 가 존재하는 상태에서 고온을 처리한 열 충격 스트레스에 대해서 방어기능을 수행하는 지를 실험하였다(Fig. 6). Fig. $6 \mathrm{~A}$ 에서 정상적인 성장온도인 $37^{\circ} \mathrm{C}$ 에 서 야생형 대장균이나 $\mathrm{dps}$ 유전자가 결손된 $\triangle \mathrm{dps}$ E.coli 돌연 변이 균주 모두 정상적인 성장 속도를 나타내는 것을 확인하 였다. 하지만, 강력한 산화 스트레스를 유발하는 과산화수소 $(0.5 \mathrm{mM})$ 와 고온 $\left(45^{\circ} \mathrm{C}\right)$ 의 열 충격을 동시에 처리하여 대장균 을 배양하였을 때 dps유전자가 결손된 $\triangle d p s$ E.coli 돌연변이 균주의 생육은 야생형 대장균에 비해 훨씬 심한 영향을 받음 으로써 성장속도 저하가 약 $80 \%$ 이상 저해됨을 확인함 할 수 있었다. 이러한 결과를 통해서 DPS 단백질은 산화적 스트레스 에 의한 대장균 보호기능뿐만 아니라 산화스트레스와 고온의 열 충격을 동시에 처리한 강력한 환경스트레스 상태에서 대단 히 중요한 기능을 수행함을 관찰할 수 있었다.

\section{산성 조건 하에서 DPS 단백질이 대장균의 생육에 미치는 영향}

생물체 내의DNA는 산성 조건에서 피해를 받아 이로 인하 여 depurination과 depyrimidination이 유발되기 때문에 배지 의 $\mathrm{pH}$ 는 생물체 성장에 저해효과를 유발하게 된다는 것이 알 려져 있다[17]. 뿐만 아니라, 산성 조건에서의 세포질 산성화는 효소의 활성에도 심각한 영향을 주게 되어 활성을 저해시키게 된다. 따라서, 하등생물체인 대장균이나 다른 bacteria는 산성 에 노출된 세포가 세포막의 구성을 바꾸는 능력, 선천적인 세 포질의 $\mathrm{pH}$ 의 효소에 의한 항상성 조절 그리고 생체 거대분자 들의 피해에 대한 복구 혹은 예방을 하는 세 가지 주요한 방어
전략을 가진다는 사실이 알려져 있다 $[3,5,7,15,16]$. 정상적인 $\mathrm{pH} 7.0$ 의 중성상태 배지에서는 야생형 대장균이나 dps유전자 가 결손된 $\triangle d p s$ E.coli 돌연변이 대장균 균주 모두 잘 성장함을 관찰할 수 있었다. 하지만, 정상보다 낮은 $\mathrm{pH}$ 조건인 $\mathrm{pH} 5$ 인 배지에서 야생형 대장균은 비교적 잘 성장하고 있음을 알 수 있었으나, dps유전자가 결손된 $\triangle d p s$ E.coli 돌연변이 균주는 성장속도가 야생형 대장균에 비하여 약 $20 \%$ 정도 더 많은 저 해된 생육상태를 보여주었다(Fig. 7). 이 결과에서 볼 수 있듯 이, DNA와 결합하여 복합체를 구성하는 DPS 단백질은 대장 균이 성장하는 배지 용액의 낮은 $\mathrm{pH}$ 조건에서 대장균이 성장 하는데 매우 중요한 기능을 수행함을 알 수 있었다. 이러한 결과로부터 우리는 DPS 단백질이 DNA와 결합하여 외부의 $\mathrm{pH}$ 변화에 따른 유전정보 가닥의 파괴를 보호하는 중요한 기 능을 수행한다는 것을 규명할 수 있었다.

\section{고 찰}

본 실험을 통해서 대장균은 DPS 단백질 발현을 통하여 다 양한 외부의 환경 스트레스에 대해 저항성을 가지게 된다는 것을 규명하였다. 본 실험의 결과로부터 DPS 단백질은 대장균 세포 내에서 유전물질인 DNA와 강하게 결합하여 외부 환경 스트레스로부터 유전물질의 변화를 보호하게 되고 이를 통하 여 미생물의 생육을 원활하게 유지시켜 줄 수 있다는 사실을 확인하였다. 그리고 이 실험 결과는 DPS의 기능이 세포 내의 유전자와 결합하여 생명체를 보호하는데 주된 역할을 수행한 다는 선행결과와 잘 일치함을 알 수 있었다[4].

또한 DPS 단백질의 스트레스 저항성 기능 이외에 생체내의 다양한 역할과 기능을 수행한다고 추측되기 때문에 이 단백질 의 다른 기능규명에 대하여도 아직 해결해야 할 과제가 많이 남아 있다. 특히, 미생물의 생육조건에서 주변 환경이 다시 


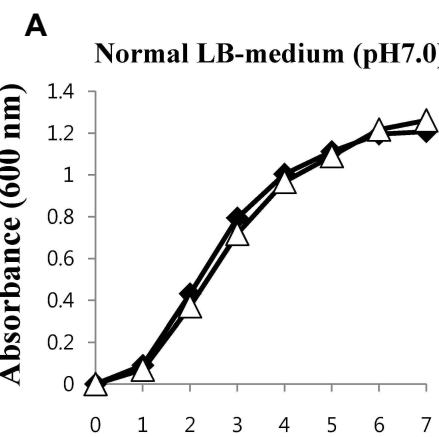

Time (hr)

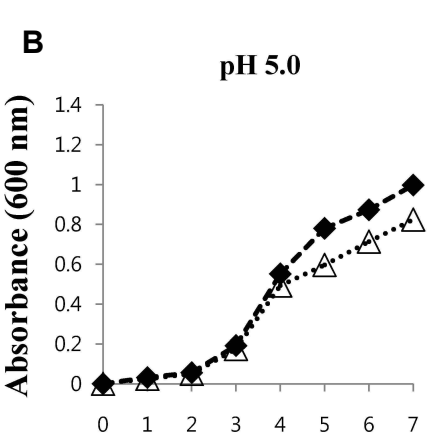

Time (hr)

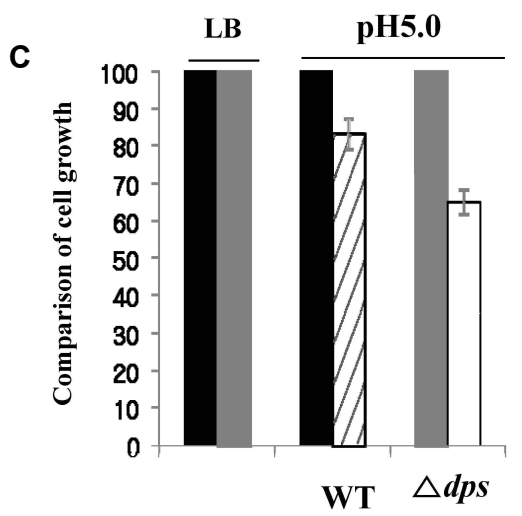

Fig. 7. Growth curve of wild-type $E$. coli $(\checkmark)$ and $d p s$ - knock out mutant $(\triangle d p s) E$. coli cells $(\triangle)$ cultured in LB-media at different $\mathrm{pHs}$, such as at pH 7.0 (A) and at pH 5.0 (B). Cell growth was measured at indicated times $(0,1,2,3,4,5,6,7 \mathrm{hr})$ by UV-spectrorphotometer in absorbance $600 \mathrm{~nm}$. The cell densities of $\triangle$ dps cells at $7 \mathrm{hr}$ were compared with those of wild type E. coli (C). Normal condition WT $(\square)$ and $\triangle d p s(\square)$. Stress condition WT $(\square)$ and $\triangle d p s(\square)$.

원 상태로 복구 되었을 경우에 DPS와 DNA 복합체는 빠르게 해리되어야 하며 유전자의 전사 및 해독과정을 수행하여야 할 것이다. 현재 보고된 연구들에 의하면 DPS 단백질은 $\mathrm{ClpXP}$ 와 ClpAP 단백질분해효소들에 의해서 분해가 된다 [25]. 하지만 ClpXP에 의한 post-translational 단계에서의 조 절과 $\mathrm{ClpAP}$ 에 의한 translational 단계에서의 조절들에 대한 mechanism에 관여하는 단백질이나 혹은 그 결합이 해체되는 과정 등에 대해서는 아직 더 많은 연구가 필요하다.

우리는 DPS의 뛰어난 생체방어 능력과 산화적 스트레스에 대한 저항성을 활용하여 많은 실생활에 활용할 수 있도록 접 목할 수 있을 것으로 판단된다. 지구상에서 살아가는 생물들 은 산소에 노출되어 있기에 대사활동을 하게 될 경우, 활성 산소종이 생성되고 이로 인한 세포 사멸, 수명감축 등이 유발 되는데 이는 각각의 생물들이 스스로 예방하고 복구하는 시스 템을 가지고는 있지만 환경 스트레스에 약한 한계가 있기 마 련이다. 그러므로 DPS를 다른 생물에 도입 할 수 있는 방법을 찾고 안정적으로 기능을 수행할 수 있게 된다면 활성산소종 및 외부의 환경스트레스에 대한 저항성은 생물체의 생육과정 에서 커다란 시너지 효과를 기대할 수 있을 것이며 이는 산업 적 이용 측면에서 대단히 중요한 의미를 갖는 응용성을 가지 게 될 것이다.

\section{결 론}

대장균 세포내의 유전자와 강한 결합을 하는 DPS 단백질은 영양부족, 산성배지, 활성산소종, 산화스트레스와 열 충격 등 의 다양한 환경스트레스 조건 하에서 대장균의 유전물질을 보호함으로서 대장균 세포의 성장과 생육에 중요한 기능을 수행함을 알 수 있었다.

\section{감사의 글}

이 논문은 농촌진훙청의 차세대 바이오그린21 연구과제 (SSAC, PJ008109) 연구비를 지원받아 수행되었음.

\section{References}

1. Almiro'n, M., Link, A. J., Furlong, D. and Kolter, R. 1992. A novel DNA-binding protein with regulatory and protective roles in starved Escherichia coli. Genes Dev 6, 2646-2654.

2. Altuvia, S., Almiron, M., Huisman, G., Kolter, R. and Storz, G. 1994. The DPS promoter is activated by OxyR during growth and by IHF and $\sigma^{s}$ in stationary phase. Mol Microbid 13, 265-272.

3. Brown, J. L., Ross, T., McMeekin, T. A. and Nichols, P. D. 1997. Acid habituation of Escherichia coli and the potential role of cytoplasmic fatty acids in low $\mathrm{pH}$ tolerance. Int $J$ Food Microbiol 37, 163-173.

4. Calhoun, L. N. and Kwon, Y. M. 2011. Structure, function and regulation of the DNA-binding protein DPS and its role in acid and oxidative stress resistance in Escherichia coli. J Appl Microbiol 110, 375-386.

5. Castanie-Cornet, M. P., Penfound, T. A., Smith, D., Elliott, J. F. and Foster, J. W. 1999. Control of acid resistance in Escherichia coli. J Bacteriol 181, 3525-3535.

6. Chiancone, E. and Ceci, P. 2010. Role of DPS (DNA-binding proteins from starved cells) aggregation on DNA. Front Biosci 15, 122-131.

7. Chiancone, E. and Ceci, P. 2010. The multifaceted capacity of DPS proteins to combat bacterial stress conditions: detoxification of iron and hydrogen peroxide and DNA binding. Biochim Biophys Acta 1800, 798-805.

8. Choi, S. H., Baumler, D. J. and Kaspar, C. W. 2000. Contribution of DPS to acid stress tolerance and oxidative 
stress tolerance in Escherichia coli O157:H7. Appl Environ Microbiol 66, 3911-3916.

9. Drlica, K. and Rouviere-Yaniv, J. 1987. Histonelike proteins of bacteria. Microbiol Rev 51, 301-319.

10. Grant, R. A., Filman, D. J., Finkel, S. E., Kolter, R. and Hogle, J. M. 1998. The crystal structure of DPS, a ferritin homolog that binds and protects DNA. Nat Struct Biol 5, 294-303.

11. Haikarainen, T. and Papaqeorqiou, A. C. 2010. DPS-like proteins: structural and functional insights into a versatile protein family. Cell Mol Life Sci 67, 341-351.

12. Hong, Y., Wang, G. E. and Maier, R. J. 2006. Helicobacter hepaticus DPS protein plays an important role in protecting DNA from oxidative damage. Free Radic Res 40, 597-605.

13. Ishikawa, T., Mizunoe, Y., Kawabata, S., Takade, A., Harada, M., Wai, S. N. and Yoshida, S. 2003. The iron-binding protein DPS confers hydrogen peroxide stress resistance to Campylobacter jejuni. J Bacteriol 185, 1010-1017.

14. Jeong, K. C., Baumler, D. J. and Kaspar, C. W. 2006. DPS expression in Escherichia coli O157:H7 requires an extended -10 region and is affected by the cAMP receptor protein. Biochim Biophys Acta 1759, 51-59.

15. Jeong, K. C., Hung, K. F., Baumler, D. J., Byrd, J. J. and Kaspar, C. W. 2008. Acid stress damage of DNA is prevented by DPS binding in Escherichia coli O157:H7. BMC Microbiol 8, 181.

16. Jordan, K. N., Oxford, L. and O'Byrne, C. P. 1999. Survival of low-pH stress by Escherichia coli O157:H7: correlation between alterations in the cell envelope and increased acid tolerance. Appl Environ Microbiol 65, 3048-3055.

17. Lindahl, T. and Nyberg, B. 1972. Rate of depurination of native deoxyribonucleic acid. Biochemistry 11, 3610-3618.

18. Malone, A. S., Chung, Y. K. and Yousef, A. E. 2006. Genes of Escherichia coli O157:H7 that are involved in high-pressure resistance. Appl Environ Microbiol 72, 2661-2671.
19. Martinez, A. and Kolter, R. 1997. Protection of DNA during oxidative stress by the nonspecific DNA-binding protein DPS. J Bacteriol 179, 5188-5194.

20. McGhee, J. D. and Felsenfeld, G. 1980. Nucleosome structure. Annu Rev Biochem 49, 1115-1156.

21. Miller, J. H. 1972. Experiments in olecular Genetics. Cold Spring Harbor Labortory Cold Spring Hatbor NY 466.

22. Nair, S. and Finkel, S. E. 2004. DPS protects cells against multiple stresses during stationary phase. J Bacteriol 186, 4192-4198.

23. Ren, B., Tibbelin, G., Kajino, T., Asami, $\mathrm{O}$ and Ladenstein, R. 2003. The multi-layered structure of DPS with a novel di-nuclear ferroxidase center. J Mol Biol 329, 467-477.

24. Saris, Per E. J., Paulin, Lars G. and Uhlen, Mathias.1990. Direct amplication of DNA from colonies of Bacillus subtilis and Escherichia coli by the polymerase chain reaction. $J$ Microbiol Methods 11, 121-126.

25. Schmidt, R., Zahn, R., Bukau, B. and Mogk, A. 2009. ClpS is the recognition component for Escherichia coli substrates of the N-end rule degradation pathway. Mol Microbiol 72, 506-517.

26. Storz, G. and Imlay, J. A. 1999. Oxidative stress. Curr Opin Microbiol 2, 188-194.

27. Wolf, S. G., Frenkiel, D., Arad, T., Finkel, S. E., Kolter, R. and Minsky, A. 1999. DNA protection by stress-induced biocrystallization. Nature 400, 83-85.

28. Yu, M. J., Ren, J., Zeng, Y. L., Zhou, S. N. and Lu, Y. J. 2009. The Legionella pneumophila DPS homolog is regulated by iron and involved in multiple stress tolerance. $J$ Basic Microbiol 49, S79-S86.

29. Zhao, G., Ceci, P., Ilari, A., Giangiacomo, L., Laue, T. M., Chiancone, E. and Chasteen, N. D. 2002. Iron and hydrogen peroxide detoxification properties of DNA-binding protein from starved cells. J Biol Chem 277, 27689-27696.

\section{초록 : 대장균 세포 내 다양한 외부 스트레스에 대한 DPS 단백질의 생리적 기능}

이주형 ${ }^{1} \cdot$ 정수진 ${ }^{1} \cdot$ 오훈택 $^{2} \cdot$ 김외연 $^{2} \cdot$ 정영준 $^{2}{ }^{*}$

( ${ }^{1}$ 경상대학교 사범대학 부설고등학교, ${ }^{2}$ 경상대학교 응용생명과학부)

대장균에서 DNA 결합 단백질로 확인된 DNA-binding Protein from Staved cells (DSP)는 DNA를 보호하는 중요한 기능을 한다는 것을 보여주었다. 이 연구의 목표는 야생형 대장균과 dps 유전자 결손 대장균 $(\triangle d p s$ E.coll $)$ 의 특성 비교를 통해 여러 종류의 스트레스에 대해 대장균에서 DPS의 기능적 역할을 설명하는 것이다. 다양한 스트레스 상태에서 자외선 흡광도계(UV-spectrophotometer)를 이용하여 야생형 대장균과 dps 유전자 결손 대장 균의 세포성장을 측정하였으며, 각각의 대장균 세포 성장 속도를 비교함으로써 우리는 대장균에 존재하는 DPS 단백질의 기능적 역할을 확인하였다. 야생형 대장균에 비해 dps 유전자 결손 대장균은 영양분 결핍, 산성화, 열 충격, 다양한 활성산소종 스트레스들에 민감한 현상을 나타내었으며, 이것은 DPS가 다양한 극단적인 스트레스에 중요한 기능을 한다는 것을 제안하였다. 결론적으로 대장균의 DPS는 다양한 환경적인 스트레스로부터 DNA와 강하게 결합하여 유지함으로써 세포를 보호하고 세포성장에 결정적인 기능을 한다는 것을 증명하였다. 